\title{
KONSTRUKSI HUBUNGAN PEMIDANAAN DENGAN TINDAK PIDANA YANG DILAKUKAN OLEH NOTARIS
}

\author{
Fanny Tanuwijaya \\ Fakultas Hukum Universitas Jember \\ J1. Kalimantan No.76, Krajan Timur, Jember \\ Email: fannytanuwijaya2018@yahoo.com
}

\begin{abstract}
Abstrak
Pemidanaan yang diberlakukan atau dikenakan pada seseorang jelas mempunyai tujuan, termasuk pada notaris. Tujuanya bukan hanya membuat jera dan mereformasi pribadi notaris yang terlibat melakukan tindak pidana, tetapi juga untuk mencegah supaya di kemudian hari tidak ada lagi notaris yang berani melakukan kejahatan atau tindak pidana yang sama. Notaris juga manusia biasa, meskipun dirinya menyandang profesi khusus, yang bisa saja terjerumus melakukan tindak pidana, sehingga pemberlakuan pemidanaan juga harus berlaku padanya secara egaliter, dan bahkan karena profesinya ini pula, penjatuhan hukuman yang bersifat pemberatan pantas diberlakukan padanya.
\end{abstract}

Kata kunci: notaris, profesi, tindak pidana, pemidanaan

\section{Abstract}

Punishment enforced or imposed on someone clearly has a purpose, including the notary. The aim is not only to deter and reform the notary who is involved in committing a criminal act, but also to prevent the notary from daring to commit the same crime or criminal act in the future. Notaries are also ordinary human beings, even though they carry a special profession, which can be caught in criminal acts, so that the imposition of punishment must also apply to him in an egalitarian manner, and even because of his profession, appropriate sentencing is imposed on him.

Keywords: notary, profession, criminal act, punishment

\section{PENDAHULUAN}

Van Kan dalam bukunya "Inleiding tot de Rechtweten schap" menulis bahwa terdapat kaedah-kaedah agama, kesusilaan, kesopanan, yang semuanya bersama-sama ikut berusaha dalam penyelenggaraan dan perlindungan kepentingan-kepentingan orang dalam masyarakat, sehingga secara khusus hukum bertujuan menjaga kepentingan tiap-tiap manusia supaya kepentingan-kepentingan itu tidak dapat diganggu. ${ }^{1}$ Kepentingan

\footnotetext{
${ }^{1}$ Ahmad Ubaidillah, Menjelajahi Hukum, (Jakarta: Persada Media, 2010), hal. 2-3.
} 
manusia yang dijaga ini menjadi tujuan hokum, karena kalau tidak dijaga atau dilindungi, akan terjadi kondisi yang saling menunjukkan atau menampilkan aktifitas yang merugikan, seperti melanggar hak orang lain. ${ }^{2}$

Pada saat ini oleh masyarakat umum telah diterima pendapat bahwa negaralah yang berhak memidana dengan perantaraan aparatur hukum pemerintahan. Oleh karena negara mempunyai kekuasaan, maka pidana yang dijatuhkan hanyalah suatu alat untuk mempertahankan tata tertib negara. Negara harus mengembalikan ketentraman apabila ketentraman itu terganggu dan harus mencegah perbuatan-perbuatan yang melanggar hukum. Seperti halnya yang dikemukakan oleh Hans, bahwa: ${ }^{3}$ sanksi itu diancamkan terhadap seorang individu yang perbuatannya dianggap oleh pembuat Undang-Undang membahayakan masyarakat, dan oleh sebab itu pembuat Undang-Undang bemaksud untuk mencegahnya dengan sanksi tersebut. Pada zaman Yunani dahulu oleh Plato mengemukakan bahwa tujuan pemidanaan bukanlah pembalasan, tetapi menakut-nakuti dan memperbaiki orang serta tercapainya keamanan". Sedangkan Aristoteles berpendapat bahwa tujuan pidana adalah "menakut-nakuti serta memperbaiki orang". Pada abad pertengahan Thomas Aquino, sebagai seorang ahli filsafat sebenarnya mempertahankan pendapat Aristoteles yang antara lain berpendapat bahwa tujuan pidana ialah "bukanlah pebalasan semata-mata tetapi disesuaikan dengan tujuan negara yaitu kesejahteraan serta memperbaiki dan menakutkan". ${ }^{4}$

Sehubungan dengan tujuan pemidanaan tersebut Sneca, seorang filosof Romawi yang terkenal sudah membuat formulasi yakni nemo prudens puint quia peccatum est, sed ne peccetur, yang artinya adalah tidak layak orang memidana karena telah terjadi perbuatan salah, tetapi dengan maksud agar tidak terjadi lagi perbuatan yang salah. ${ }^{5}$

Begitu pula Jeremy Benthanm dan sebagian besar penulis modern yang lain selalu menyatakan bahwa tujuan pemidanaan adalah "untuk mencegah dilakukannya kejahatan pada masa yang akan datang". Dilain pihak Immanuel Kant dan Gereja Katolik sebagai pelopor menyatakan, bahwa "pembenaran pidana dan tujuan pidana adalah pembalasan terhadap serangan kejahatan atas ketertiban sosial dan moral". ${ }^{6}$

${ }^{2}$ Hilman Hariri, Hukum dalam Pusaran Kepentingan Global, (Jakarta: Tinta Mas, 2015). Hal. 11.

${ }^{3}$ Hans Kelsen, Teori dan Metodologi Penelitian Hukum Normatif, (Malang: Bayumedia, 2006), hal. 78.

${ }^{4}$ Rusli Effendy, Azas-Azaz Hukum Pidana, (Makassar, Lembaga Percetakan Dan Penerbitan Universitas Muslim Indonesia (LEPPEN-UMI, 1986), hal. 108.

${ }^{5}$ Priyanto Dwijaya, Sistem Pelaksanaan Penjara Di Indonesia, (Bandung, Refika Aditama, 2006) hal. 23.

${ }^{6}$ Ibid., hal. 23. 
Menurut Andi Hamzah menyatakan bahwa: reformasi berarti memperbaiki atau merehabilitasi penjahat menjadi orang baik dan berguna bagi masyarakat. Masyarakat akan memperoleh keuntungan dan tiada seorangpun yang merugi jika penjahat menjadi baik. Reformasi itu perlu digabung dengan tujuan yang lain seperti pencegahan. ${ }^{7}$ Sementara H.R. Abdussalam, menyatakan bahwa: tujuan pemidanaan reformatif adalah memperbaiki kembali para narapidana. Teori ini mempunyai nama lain antara lain: rehabilitasi, pembenahan, perlakuan (perawatan). Usaha untuk memberikan program selama pemulihan benar-benar diarahkan kepada individu narapidana. ${ }^{8}$

Meskipun sudah ada sekian banyak kalangan profesional yang paham tentang makna atau tujuan pemidanaan, tetapi faktanya kalangan professional, termasuk di dalamnya notaris, tidak sedikit diantaranya yang terjerums melakan tindak pidana, yang tindak pidana ini jenis dan polanya berkaitan dengan profesinya.

\section{PEMBAHASAN \\ Idealisme Pemidanaan}

Banyak ahh yang sudah membahas soal pidana dan tindak pidana. Menurut Van Hamel, ${ }^{9}$ bahwa arti dari pidana itu atau straf adalah suatu penderitaan yang bersifat khusus, yang telah dijatuhkan oleh kekuasaan yang berwenang untuk menjatuhkan pidana atas nama negara sebagai penanggungjawab dari ketertiban umum bagi seorang pelanggar,yakni semata-mata karena orang tersebut telah melanggar suatu peraturan atau hukum yang harus ditegakkan oleh negara.

Pandangan Simons berbeda lagi. Menurunya pidana adalah suatu penderitaan yang oleh Undang-Undang pidana telah dikaitkan dengan pelanggaran terhadap suatu norma, yang dengan suatu putusan hakim yang telah dijatuhkan bagi seseorang yang bersalah. ${ }^{10}$ Begitu pula dengan Algranjanssen, telah merumuskan: ${ }^{11}$ pidana atau straf sebagai alat yang dipergunakan oleh penguasa (hakim) untuk memperingatkan mereka yang telah melakukan suatu perbuatan yang tidak dapat dibenarkan. Reaksi dari penguasa tersebut telah mencabut kembali sebagian dari perlindungan yang

${ }^{7}$ Andi Hamzah, Sistem Pidana dan Pemidanaan Indonesia dari Retribusi di Reformasi, )Jakarta: Pradaya Paramita, 1994), hal. 28.

${ }^{8}$ Abdussalam, Prospek Hukum Pidana Indonesia (Dalam Mewujudkan Keadilan Masyarakat), (Jakarta: Restu Agung, 2006) hal. 22.

9 P.A.F. Lamintang, Dasar-Dasar Hukum Pidana Indonesia, (Bandung: Citra Aditya Bakti, 1997), hal. 47.

${ }^{10}$ Ibid., hal. 48.

${ }^{11}$ Ibid., hal. 48. 
seharusnya dinikmati terpidana atas nyawa, kebebasan dan harta kekayaannya, yaitu seandainya ia telah melakukan suatu tindak pidana.

Dalam tulisan Sudarto, salah satu istilah yang berkaitan dengan perbuatan melanggar norma hukum adalah istilah tindak pidana. Istilah tindak pidana merupakan terjemahan dari bahasa Belanda yaitu dari perkataan "Strafbaar Feit " yang diterjemahkan sebagai suatu perbuatan yang dilarang oleh suatu aturan hukum, larangan mana disertai ancaman (sanksi) berupa pidana tertentu. ${ }^{12}$

Adapun para ahli hukum pidana Indonesia yang menggunakan istilah-istilah tersebut antara lain; E. Utrecht, menggunakan istilah peristiwa pidana, Moeljatno menggunakan istilah perbuatan pidana, dan Sudarto, menggunakan istilah tindak pidana. Pemakaian istilah yang berlainan itu tidak menjadi soal, asal diketahui apa yang dimaksud, dan dalam hal ini yang penting adalah isi dari tindak pidana seperti yang dilakukan oleh pembentuk undang-undang. Dalam hal ini Muljatno tetap mempergunakan istilah tersebut karena sudah dapat diterima oleh masyarakat. ${ }^{13}$

Perbuatan pidana adalah perbuatan yang dilarang oleh suatu aturan hukum yang disertai dengan ancaman (sanksi) berupa pidana tertentu bagi yang melanggar larangan tersebut. Dapat juga dikatakan bahwa perbuatan pidana adalah perbuatan yang oleh suatu aturan hukum dilarang dan diancam pidana, yang mana larangannya ditujukan kepada perbuatannya (yaitu suatu keadaan atau kejadian yang ditimbulkan oleh kelakuan orang) sedangkan ancaman pidananya ditujukan kepada orang yang menimbulkan kejadian itu.

Antara larangan dengan ancaman pidana ada hubungan yang erat, oleh karena itu antara kejadian dan orang yang menimbulkan kejadian tersebut juga mempunyai hubungan yang erat. Karena kejadian tidak bisa dilarang jika yang melakukan bukan manusia, dan orang tidak dapat diancam pidana jika tidak melakukan apa-apa. Untuk menyatakan hubungan yang erat itu, maka dipakailah istilah perbuatan pidana, yaitu suatu pengertian abstrak yang menunjuk kepada dan keadaan konkrit yaitu adanya kejadian dan adanya orang yang berbuat yang menimbulkan kejadian tersebut.

Istilah lain yang dipakai dalam hukum pidana yaitu tindak pidana, istilah ini tumbuh dari pihak Kementerian Kehakiman dan sering dipakai

\footnotetext{
${ }^{12}$ Sudarto, Hukum Pidana 1, Yayasan Sudarto, (Semarang: Universitas Diponegoro, 1991), hal. 39.

${ }^{13}$ Moeljatno, Asas-asas Hukum Pidana, (Jakarta: Rineka Cipta, 1993), hal. 35,
} 
dalam perundang-undangan. Tindak pidana adalah perbuatan orang yang malakukan atau tidak melakukan sesuatu yang oleh peraturan perundangundangan dinyatakan sebagai perbuatan yang dilarang dan diancam dengan pidana. ${ }^{14}$ Berdasarkan ketiga rumusan mengenai pidana diatas dapat diketahui, bahwa pidana itu sebenarnya hanya merupakan suatu penderitaan atau suatu alat belaka.

Menjatuhkan pidana tidak dimaksudkan untuk mencapai sesuatu yang praktis, tetapi bermaksud satu-satunya penderitaan bagi penjahat. ${ }^{15} \mathrm{Di}$ dalam buku E.Y. Kanter dan S.R. Sianturi Teori pembalasan ini terbagi atas lima, yaitu sebagi berikut $:^{16}$

1) Pembalasan berdasarkan tuntutan mutlak dari ethica(moraal philosofie). Teori ini dikemukakan oleh Immanuel Kant yang mengatakan bahwa pemidanaan adalah merupakan tuntutan mutlak dari kesusilaan (etika) terhadap seorang penjahat. Ahli filsafat ini mengatakan bahwa dasar pemidanaan adalah tuntutan mutlak dari kesusilaan kepada seorang penjahat yang telah merugikan orang lain.

2) Pembalasan "bersambut" (dialektis). Teori ini dikemukakan oleh Hegel, yang mengatakan bahwa hukum adalah perwujudan dari kemerdekaan, sedangkan kejahatan adalah merupakan tantangan kepada hukum dan keadilan.

3) Pembalasan demi "keindahan" atau kepuasan (aesthetisch). Teori ini dikemukakan oleh Herbart, yang mengatakan bahwa pemidanaan adalah merupakan tuntutan mutlak dari perasaan ketidakpuasan masyarakat, sebagai akibat dari kejahatan, untuk memidana penjahat, agar ketidakpuasan masyarakat terimbangi atau rasa keindahan masyarakat terpulihkan kembali.

4) Pembalasan sesuai dengan ajaran Tuhan (Agama). Teori ini dikemukakan oleh Dthal, (termasuk juga Gewin dan Thomas Aquino) yang mengemukakan, bahwa keajahatan merupakan pelanggaran terhadap pri-keadilan Tuhan dan harus ditiadakan. Karenanya mutlak harus diberikan penderitaan kepada penjahat, demi terpeliharanya keadilan Tuhan.

${ }^{14}$ Sunardi dan Fanny Tanuwijaya., Tindak Pidana Nyawa Badan, (Malang: Lembaga Penerbitan Fakultas Hukum Unisma, 1991), hal. 1.

${ }^{15}$ Adami Chazawi, Pelajaran Hukum Pidana Bagian I Stelsel Pidana, Teori-Teori Pemidanaan \& Batas Berlakunya Hukum Pidana. (Jakarta : PT Raja Grafindo, 2002). hal. 153-154.

${ }^{16}$ E.Y. Kanter Dan S.R. Sianturi, Asas-asas Hukum Pidana Di Indoneisa Dan Penerapannya, (Jakarta, Storia Grafika. 2002), hal. 59-60. 
5) Pembalasan sebagai kehendak manusia. Para sarjana dari mashab hukum alam yang memandang negara sebagai hasil dari kehendak manusia, mendasarkan pemidanaan juga sebagai perwujudan dari kehendak manusia. Menurut ajaran ini adalah merupakan tuntutan alam bahwa siapa saja yang melakukan kejahatan, dia akan menerima sesuatu yang jahat. Penganut teori ini antara lain adalah Jean Jacques Roesseau, Grotius, Beccaria dan lain sebagainya.

Teori tentang tujuan pidana yang kedua adalah teori relatif. Teori mencari dasar hukum pidana dalam menyelenggarakan tertib masyarakat dan akibatnya yaitu tujuan untuk prevensi terjadinya kejahatan. Menurut teori ini, memidana bukanlah untuk memutuskan tuntutan absolut dari keadilan. Pembalasan itu sendiri tidak mempunyai nilai, tetapi hanya sebagai sarana untuk melindungi kepentingan masyarakat.

Muladi dan Barda Nawawi Arif, menyatakan bahwa pidana mempunyai tujuan-tujuan tertentu yang bermanfaat. Oleh karena itu teori inipun sering juga disebut teori tujuan (utilitarian teory). Jadi dasar pembenaran pidana menurut teori ini adalah terletak pada tujuannya. Pidana dijatuhkan bukan quia peccatumest (karena orang membuat kejahatan) melainkan ne peccatum (supaya orang jangan melakukan kejahatan). ${ }^{17}$

Menurut J. Andenas, teori ini dapat disebut sebagai teori perlindungan masyarakat (the theory of social defence). Sedangkan Nigel Walker teori ini lebih tepat disebut teori atau aliran reduktif (the reductive foint of view) karena dasar pembenaran pidana menurut teori ini adalah untuk mengurangi frekuensi kejahatan. Oleh karena itu penganutnya dapat disebut golongan Reducers (penganut teori reduktif). ${ }^{18}$

Menurut Adami Chazawi, mengemukakan bahwa: teori relatif atau tujuan berpangkal pada dasar bahwa pidana adalah alat untuk menegakkan tata tertib (hukum) dalam masyarakat. Tujuan pidana ialah tata tertib masyarakat, dan untuk mengakkan tata tertib itu diperlukan pidana. Pidana adalah alat untuk mencegah timbulnya suatu kejahatan, dengan tujuan agar tata tertib masyarakat tetap terpelihara. ${ }^{19}$ Menurut teori ini tujuan pidana adalah mengamankan masyarakat dengan jalan menjaga serta mempertahankan tata tertib masyarakat. Dalam menjaga serta mempertahankan tata tertib masyarakat ini, maka pidana itu adalah bertujuan untuk menghindarkan pelanggaran norma-norma hukum. Untuk menghindarkan pelanggaran norma-norma hukum ini, pidana itu dapat bersifat menakuti, memperbaiki dan dapat juga bersifat membinasakan.

\footnotetext{
${ }^{17}$ Dwidjaya Priyanto, Op.Cit. hal. 25.

${ }^{18}$ Ibid., hal. 149.

${ }^{19}$ Adami Chazawi, Op.Cit. hal. 157-158.
} 
Sehubungan dengan sifat pidana tersebut Leden Marpaung, memaparkan sebagai berikut: ${ }^{20}$

a. Menjerakan. Dengan penjatuhan pidana, diharapkan sipelaku atau terpidana menjadi jera dan tidak mengulangi lagi perbuatannya (speciale preventive) serta masyarakat umum mengetahui bahwa jika melakukan pebuatan sebagaimana dilakukan terpidana, mereka akan mengalami hukuman yang serupa (generale preventive).

b. Memperbaiki pribadi terpidana Berdasarkan perlakuan dan pendidikan yang diberikan selama menjalani pidana, terpidana merasa menyesal sehingga ia tidak akan mengulangi perbuatannya dan kembali kepada masyarakat sebagai orang yang baik dan berguna.

c. Membinasakan atau membuat terpidana tidak berdaya. Membinasakan berarti menjatuhkan hukuman mati, sedangakan membuat terpidana tidak berdaya dilakukan dengan menjatuhkan hukuman seumur hidup.

Jadi menurut teori relatif pidana ini sebenarnya bersifat menghindarkan (prevensi) dilakukannya pelanggaran hukum. Sifat prevensi dari pidana terbagi atas dua bagian yakni prevensi khusus dan prevensi umum. Prevensi khusus berkaitan dengan maksud dan tujuan pidana ditinjau dari segi individu, karena prevensi khusus ini bermaksud juga supaya seseoang yang bersalah jangan lagi melakukan pelanggaran.

Menurut prevensi khusus tujuan pidana tidak lain ialah bermaksud menahan niat buruk pembuat, yang didasarkan kepada pikiran bahwa pidana itu dimaksudkan supaya orang yang bersalah itu tidak berbuat kesalahan lagi. Seperti halnya yang dikemukakan oleh Van Hammel dari Belanda bahwa tujuan pemidanaan, selain untuk mempertahankan ketetiban masyarakat, juga mempunyai tujuan kombinasi untuk melakukan (ofschrikking), memperbaiki (verbetering) dan untuk kejahatan tertentu harus membinasakan (onskchadelijkmaking). ${ }^{21}$

Tujuan pemidaanaan memperbaiki sipenjahat, agar menjadi manusia yang baik. Menjatuhkan pidana harus disertai pendidikan selama menjalani pidana. Pendidikan yang diberikan terutama untuk disiplin dan selain itu diberikan pendidikan keahlian seperti menjahit, bertukang dan lain sebagainya, sebagi bekal setelah selesai menjalani pemidanaan. Cara perbaikan penjahat dikemukakan ada tiga macam yaitu perbaikan, intelektual, dan perbaikan moral serta pebaikan yuridis.

Prevensi umum bertujuan untuk mencegah orang pada umumnya jangan melanggar karena pidana itu dimaksudkan untuk menghalanghalangi supaya orang jangan berbuat salah. Teori prevensi umum mengajarkan bahwa untuk mempertahankan ketertiban umum pada kaum penjahat, maka

\footnotetext{
${ }^{20}$ Leden Marpaung, Op.Cit. hal. 4.

${ }^{21}$ H.R. Abdussalam, Op.Cit. hal. 31.
} 
penjahat yang tertangkap harus dipidana berat supaya orang laian takut melanggar peraturan-peraturan pidana.

Dalam teori prevensi umum ini, tujuan pokok yang hendak dicapai adalah pencegahan yag ditujukan kepada khalayak ramai atau semua orang agar tidak melakukan pelanggaran terhadap ketertiban masyarakat. Menurut H.B. Vos, menyatakan bahwa "teori prevensi umum bentuknya berwujud pemidanaan yang mengandung sifat menjerakan atau menakutkan". ${ }^{22}$

Dengan adanya keberatan terhadap teori pembalasan dan teori tujuan, maka lahir aliran ketiga yang didasarkan pada jalan pemikiran bahwa pemidanaan hendaknya didasarkan atas tujuan unsur-unsur pembalasan dan mempertahankan ketertiban masyarakat, yang diterapkan secara kombinasi dengan menitikberatkan pada salah satu unsurnya tanpa menghilangkan unsur yang lain, maupun pada semua unsur yang ada.

Menurut Grotius, menyatakan bahwa: ${ }^{23}$ teori gabungan ini sebagai pemidanaan berdasarkan keadilan absolute, "de absolute gerechtighaeid" yang berwujud pemabalasan terbatas kepada apa yang berfaedah bagi masyarakat dan dikenal dengan bahasa latin "piniendus nemo est iltra meritum, intra meriti vero modum magis out minus peccata puniuntur pro utilitate", artinya tidak seorangpun yang dipidana sebagai ganjaran, yang diberikan tentu tidak melampaui maksud,tidak kurang atau tidak lebih dari kefaedahan.

Teori ini adalah kombinasi antara penganut teori pemabalasan dan teori tujuan, yaitu membalas kejahatan atau kesalahan penjahat dan melindungi masyarakat; dan kedua tujuan ini disusul dengan memidana. Ada yang mengutamakan tujuan membalas, agar kejahatan itu dibalas dengan pidana yang lebih berat daripada melindungi masyarakat. Adapun yang lain berpendapat bahwa tujuan pidana yang pertama ialah melindungi masyarakat, akan tetapi untuk mencapai tujuan itu tidak boleh dijatuhkan pidana lebih berat daripada membalas kesalahan pembuat atau kesengsaraan yang diadakan olehnya.

Van Apeldorn, menyatakan bahwa, teori gabungan ini tepat benar karena mengajarkan bahwa pidana diberikan baik quia peccatum est (karena orang membuat kejahatan) maupun nepeccatur (supaya orang jangan membuat kejahatan). ${ }^{24}$ Asas pembalasan yang kuno tidak berlaku lagi, malah diantara mereka yang masih menganggapnya penting, ada kesediaan untuk memperhatikan aspek-aspek sosial defence dari pidana.

Untuk membandingkan dengan teori-teori tentang tujuan pemidanaan seperti yang dikemukakan di atas, maka dalam rancangan

\footnotetext{
${ }^{22}$ Ibid., hal. 32.

${ }^{23}$ Ibid., hal. 32.

${ }^{24}$ Rusli Effendy, Op.Cit. hal. 116.
} 
Undang-Undang tentang Kitab Undang-Undang Hukum Pidana 1982 dapat dijumpai gagasan tentang maksud tujuan pemidanaan dalam rumusan sebagai berikut:

(1) Untuk mencegah dilakukannya tindak pidana demi pengayoman negara, masyarakat dan penduduk.

(2) Untuk membimbing agar terpidana insaf dan menjadi anggota masyarakat yang berbudi baik dan berguna, serta mampu untuk hidup bermasyarakat.

(3) Menyelesaikan konflik yang ditimbulkan oleh tindak pidana, memulihkan keseimbangan dan mendatangkan rasa damai pada masyarakat.

(4) Pemidanaan tidak dimaksudkan untuk menderitakan dan tidak diperkenangkan merendahkan martabat manusia melainkan untuk membebaskan rasa bersalah pada terpidana. ${ }^{25}$

Pidana dijatuhkan bukan hanya semata-mata karena pelaku telah berbuat jahat tetapi agar pelaku kejahatan tidak lagi melakukan kejahatan dan orang lain takut untuk melakukan kejahatan serupa. Berdasarkan penyataan di atas, terlihat bahwa tujuan pemidanaan itu sama sekali bukan dimaksudkan sebagai upaya balas dendam melainkan sebagai upaya pembinaan bagi seorang pelaku kejahatan sekaligus upaya preventif untuk mencegah terjadinya kejahatan serupa.

\section{Tindak Pidana yang dilakukan Notaris}

Notaris diangkat oleh pemerintah bukan untuk kepentingan diri notaris sendiri melainkan untuk kepentingan masyarakat yang membutuhkan jasanya, sehingga pembinaan dan pengawasan terhadap notaris yang semula dilakukan oleh Pengadilan Negeri dimana wilayah jabatan Notaris tersebut kini berada dibawah wewenang Menteri hukum dan HAM Republik Indonesia sebagaimana Undang-undang Nomor 30 Tahun 2004 tentang Jabatan Notaris. Meski sudah ada pembaruan, tapi UndangUndang Nomor 30 Tahun 2004 tentang Jabatan Notaris ini dinilai terdapat sejumlah kekurangan, sehingga akhirnya diperbarui dengan UU yang lebih baru, yakni Undang-Undang Republik Indonesia Nomor 2 Tahun 2014 Tentang Perubahan Atas Undang-Undang Nomor 30 Tahun 2004 Tentang Jabatan Notaris.

Undang-Undang Republik Indonesia Nomor 2 Tahun 2014 ini menggunakan pertimbangan berikut: a. bahwa Negara Republik Indonesia sebagai negara hukum berdasarkan Pancasila dan Undang-Undang Dasar Negara Republik Indonesia Tahun 1945 menjamin kepastian, ketertiban, hal. 10 .

${ }^{25}$ Djoko Prakoso, Hukum Panitensier Di Indonesia, (Yogyakarta: Liberty, 1988), 
dan perlindungan hukum bagi setiap warga negara; b. bahwa untuk menjamin kepastian, ketertiban, dan perlindungan hukum dibutuhkan alat bukti tertulis yang bersifat autentik mengenai perbuatan, perjanjian, penetapan, dan peristiwa hukum yang dibuat di hadapan atau oleh pejabat yang berwenang; c. bahwa Notaris sebagai pejabat umum yang menjalankan profesi dalam memberikan jasa hukum kepada masyarakat, perlu mendapatkan perlindungan dan jaminan demi tercapainya kepastian hukum; d. bahwa beberapa ketentuan dalam Undang-Undang Nomor 30 Tahun 2004 tentang Jabatan Notaris sudah tidak sesuai lagi

Notaris adalah pejabat umum yang berwenang dan mewakili kekuasaan umum untuk membuat akta autentik dan kewenangan lainnya sebagaimana dimaksud dalam Undang-Undang ini, untuk kepentingan pembuktian atau sebagai alat bukti. Secara yuridis dapat dideskripsikan, bahwa tugas notaris adalah mengkonstantir hubungan hukum antara para pihak dalam bentuk tertulis dan format tertentu, sehingga merupakan suatu akta autentik. Notaris adalah pembuat dokumen yang kuat dalam suatu proses hukum. Artinya ada proses hukum baik dalam hubungannya dengan pembuatan dokumen maupun kekuatan hukum dari dokumen yang dibuatnya $^{26}$ Namanya juga sebagai pembuat dokumen, maka kedudukan notaris ini menjadi strategis dalam ranah kepentingan hukum, baik yang bersifat khusus maupun umum.

Logis jika kemudian negara merasa perlu menata kelembagaan notariat melalui sejumlah pembatasan-pembatasan (rambu-rambu yang mengikat/menentukan), mengingat kewenangan lembaga Notariat diabdikan sepenuhnya untuk kepentingan yang lebih tinggi, yakni kepentingan masyarakat. Garis kewenangan formal yang diderivasi dari kekuasaan umum inilah yang membedakan jabatan notaris dengan profesi-profesi lainnya. ${ }^{27}$ Perbedaan inilah yang membuat jabatan notaris menjadi istimewa dibandingkan dengan lainya.

Jabatan Notaris merupakan jabatan yang keberadaannya dikehendaki guna mewujudkan hubungan hukum diantara subyek-subyek hukum yang bersifat perdata. Notaris sebagai salah satu pejabat umum mempunyai peranan penting yang dipercaya oleh pemerintah dan masyarakat untuk membantu pemerintah dalam melayani masyarakat atau memberikan jasa bersifat publik dalam menjamin kepastian, ketertiban, ketertiban dan perlindungan hukum melalui akta autentik yang dibuat oleh atau di

${ }^{26}$ Tan Thong Kie, Studi Notariat, Serba-serbi Praktek Notaris, Buku I, , (Jakarta, PT Ichtiar Baru Van Hoeve, 2002), hal.159.

${ }^{27}$ Irsyadul Anam Malaba, Pluralitas Organisasi Notaris Di antara Hak, Kebutuhan, Inefiensi dan Tafsir Pemerintah, Jurnal Renvoi, Nomor 2. 26. III Tahun Ketiga 2005, hal. 35 . 
hadapannya, mengingat akta otentik sebagai alat bukti terkuat dan memiliki nilai yuridis (kekuatan hukum) yang esensial dalam setiap hubungan hukum bila terjadi sengketa dalam kehidupan masyarakat. Notaris sebagai salah satu penegak hukum karena notaris membuat alat bukti tertulis yang mempunyai kekuatan pembuktian. Para ahli hukum berpendapat bahwa akta notaris dapat diterima dalam pengadilan sebagai bukti yang bersifat mutlak mengenai isinya, tetapi meskipun demikian dapat diadakan penyangkalan dengan bukti sebaliknya oleh saksi-saksi, yang dapat membuktikan bahwa apa yang diterangkan oleh notaris dalam aktanya adalah benar. ${ }^{28}$ Justru karena pengakuan demikian, bisa saja dijadikan sebagai salah satu kondisi untuk melakukan penyalahgunaan atau tindak pidana sehingga merugikan orang lain.

Pemerintah menghendaki notaris sebagai pejabat umum yang diangkat dan diberhentikan oleh pemerintah dan diberi wewenang dan kewajiban untuk dapat memberikan pelayanan atau jasa kepada masyarakat dalam membantu membuat perjanjian, membuat akta beserta pengesahannya yang juga merupakan kewenangan notaris, yang kewenangannya ini berimplikasi pada banyak kepentingan strategis, khususnya kepentingan hukum..

Meskipun disebut sebagai pejabat umum, namun notaris bukanlah pegawai negeri sebagaimana dimaksud dalam peraturan perundangundangan yang mengatur tentang Kepegawaian. Notaris terikat dengan peraturan perundang-undangan yang diproduk negara, seperti pengaturan bahwa notaris tidak menerima gaji dan pensiun dari pemerintah, tetapi memperoleh upah dari honorarium atau fee dari kliennya yang disepakati.

Notaris dapat dipahami secara yuridis sebagai pegawai pemerintah yang tidak menerima gaji dari pemerintah, yang juga dipensiunkan oleh pemerintah, namun tidak menerima pension dari pemerintah. Oleh karena itu, bukan saja notaris yang harus dilindungi dalam kapasitasnya sebagai pengemban profesi hukum, tetapi juga para konsumennya, yaitu masyarakat pengguna jasa notaris. Kalau pengguna jasa ini tidak dilindungi bisa terjadi mereka menjadi korban sikap dan perilaku tidak terpuji dari notaris.

Notaris sebagai pejabat publik, dalam pengertian mempunyai wewenang dengan pengecualian, dengan mengkategorikan notaris sebagai pejabat publik, dalam hal ini publik yang bermakna hukum. Notaris sebagai pejabat publik tidak berarti sama dengan Pejabat Publik dalam bidang pemerintahan yang dikategorikan sebagai Badan atau Pejabat Tata Usaha Negara, hal ini dapat dibedakan dari produk masing-masing Pejabat Publik

${ }^{28}$ Liliana Tedjosaputro, Malpraktek Notaris dan Hukum Pidana, (Semarang: CV.Agung, 1991), hal. 4 
tersebut. Notaris sebagai Pejabat Publik produk akhirnya yaitu akta autentik, yang terikat dalam ketentuan hukum perdata terutama dalam hukum pembuktian.

Kompetisi dikalangan pengemban profesi hukum seperti notaris tergolong sangat tinggi, sehingga seorang berprofesi notaris dalam menjalankan tugas jabatannya harus memiliki ketrampilan profesi di bidang hukum yang juga harus dilandasi dengan tanggungjawab dan moral yang tinggi serta pelaksanaan terhadap tugas jabatannya maupun nilai-nilai dan etika, sehingga dapat menjalankan tugas jabatannya sesuai dengan ketentuan hukum, berlandaskan etika, dan kepentingan masyarakat, ${ }^{29}$ disamping tidak sampai terjerumus melakukan tindak pidana, karena peluang melakukan atau terlibat dalam permufakatan jahat atau melakukan praktik melawan hukum pidana sangat besar terkait dengan kewenangannya yang diberikan oleh negara.

Notaris dalam melaksanakan tugasnya secara profesional harus menyadari kewajibannya, yakni bekerja sendiri dengan menunjukkan kapabilitasnya, menegakkan nilai-nilai kejujuran, tidak berpihak dan penuh rasa tanggungjawab dan memberikan pelayanan hukum kepada masyarakat yang memerlukan jasanya dengan sebaik-baiknya untuk kepentingan umum. Tuntutan demikian ini kepada notaris identik dengan mengingatkan kepada siapapun yang menjadi (menjabat) notaris, bahwa dirinya adalah pengemban profesi hukum yang secara kelembagaan berelasi dengan menjalankan praktik kenegaraan atau tugas dan kewenangannya diregulasi negara, karena memang mendapatkan amanat dari negara untuk menunjukkan ketaatannya pada kode etik profesi dan norma-norma yuridis yang menggariskannnya.

\section{KESIMPULAN}

Seseorang yang bersalah secara hukum, sudah seharusnya mempertanggngjawabkan kesalahannya. Pemidanaan merupakan konsekuensi yuridis dari setiap orang yang bersalah melakukan tindak pidana. Begitu pula, pemidanaan yang diberlakukan pada seseorang jelas mempunyai tujuan, termasuk pada notaris. Tujuanya bukan hanya membuat jera notaris yang terlibat melakukan tindak pidana, tetapi juga untuk mencegah supaya di kemudian hari tidak ada lagi notaris yang berani melakukan kejahatan atau tindak pidana yang sama.

Di satu sisi, notaris adalah pejabat umum yang diangkat oleh Negara. Namun di sisi lain, notaris juga manusia biasa, yang dalam keseharian hubungannya dengan pemohon atau penghadap yang meminta layanan jasa, bisa saja terjerumus melakukan tindak pidana, sehingga pemberlakuan

${ }^{29}$ Abdul Wahid, Sunardi, dan Mariyadi, Penegakan Kode Etik Notaris, (Jakarta: Nirmana Media, 2017), hal. 67. 
pemidanaan juga harus berlaku padanya secara egaliter atau berprinsip kesamaan derajat di depan hukum (equality before the law), dan bahkan karena profesinya ini pula, penjatuhan hukuman yang bersifat pemberatan layak diberlakukan padanya.

\section{DAFTAR PUSTAKA}

\section{Buku}

Abdul Wahid, Sunardi, dan Mariyadi, 2017, Penegakan Kode Etik Notaris, Jakarta: Nirmana Media.

Abdussalam, 2006, Prospek Hukum Pidana Indnesia (Dalam Mewujudkan Keadilan Masyarakat), Jakarta: Restu Agung.

Adami Chazawi , 2002, Pelajaran Hukum Pidana Bagian I Stelsel Pidana, Teori-Teori Pemidanaan \& Batas Berlakunya Hukum Pidana. Jakarta : PT Raja Grafindo.

Ahmad Ubaidillah, 2010, Menjelajahi Hukum, Jakarta: Persada Media.

Andi Hamzah, 1984, Sistem Pidana dan Pemidanaan Indonesia dari Retribusi di Reformasi, Jakarta: Pradaya Paramita.

Djoko Prakoso, 1988, Hukum Panitensier Di Indonesia, Yogyakarta: Liberty

E.Y. Kanter Dan S.R. Sianturi, 2002, Asas-asas Hukum Pidana Di Indoneisa Dan Penerapannya, Jakarta: Storia Grafika.

Hans Kelsen, 2006, Teori dan Metodologi Penelitian Hukum Normatif, Malang: Bayumedia.

Hilman Hariri, Hukum dalam Pusaran Kepentingan Global, Jakarta: Tinta Mas, 2015.

Liliana Tedjosaputro, 1991, Malpraktek Notaris dan Hukum Pidana, Semarang: CV.Agung,.

Moeljatno, 1993, Asas-asas Hukum Pidana, Jakarta: Rineka Cipta.

P.A.F. Lamintang, 1997, Dasar-Dasar Hukum Pidana Indonesia, Bandung, Citra Aditya Bakti.

Priyanto Dwijaya, 2006, Sistem Pelaksanaan Penjara Di Indonesia, Bandung: Refika Aditama.

Rusli Effendy, 1986, Azas-Azaz Hukum Pidana, Makassar: Lembaga Percetakan Dan Penerbitan Universitas Muslim Indonesia (LEPPENUMI).

Sudarto, 1990, Hukum Pidana 1, Yayasan Sudarto, Semarang: Universitas Diponegoro.

Sunardi dan Fanny Tanuwijaya., 2001, Tindak Pidana Nyawa Badan, Malang: Lembaga Penerbitan Fakultas Hukum Unisma. 
Tan Thong Kie, 2000, Studi Notariat, Serba-serbi Praktek Notaris, Buku I, PT Jakarta: Ichtiar Baru Van Hoeve.

\section{Jurnal}

Irsyadul Anam Malaba, Pluralitas Organisasi Notaris Di antara Hak, Kebutuhan, Inefiensi dan Tafsir Pemerintah, Jurnal Renvoi, Nomor 2. 26. III Tahun Ketiga 2005.

\section{Peraturan perundang-undangan}

Kitab Undang-undang Hukum Pidana (KUHP)

UU Nomor 2 Tahun 2014 Tentang Perubahan Atas Undang-Undang Nomor 30 Tahun 2004 Tentang Jabatan Notaris 